\title{
Analytical Study of Some Wetlands for Their Strategic Conservation and Positive Utilization
}

\author{
Jainendra Kumar ${ }^{1}$, Prashant Kumar ${ }^{2}$, Rimjhim Sheel ${ }^{3}$, and Mahindra Kumar ${ }^{4}$ \\ ${ }^{I}$ Department of Botany \& Biotechnology, College of Commerce, Patna (Bihar), India \\ ${ }^{2}$ Department of Zoology, Ram Jaipal College, Chapra (Bihar), India. \\ ${ }^{3}$ Departments of Botany, Ganga Devi Mahila Mahavidyalaya, Kaankarbagh, Patna (Bihar). \\ ${ }^{4}$ Institute of Modern Biology \& Applied Sciences, Danapur, Patna (Bihar)
}

\begin{abstract}
In-depth analytical study was carried out in five selected wetlands in the district of Madhubani (Bihar, India) in terms of their chemical parameters, biomass production and trophic relationship that was modeled with help from an ecological simulation software. These perennially water-logged bodies belonged to three categories that may be said to be (a) reverine with flowing water courses, (b) lacustrine with water depth 2 metre or more at the centre, and (c) palustrine with water less than 2 metre deep before rains. With little innovation and intensive planning, these bodies may be positively exploited for significant biomass production, aquaculture, waterfowl management and cultivation of economically useful crops including fibre yielding plants a few of which can be additionally customized to get rid of undesirable pollutants and heavy metals carried in by the in-flowing water stream or run off water during rains. The paper suggests a well-documented scheme for proper utilization and conservation of these water bodies and discusses a research protocol with three-pronged approach that includes genetic induction of heavy metal tolerance and disposal ability into a common sub-aquatic plant Typha angustifolia Linn. that is well-suited for cultivation in such conditions, while simultaneously being highly exploitable economically in terms of food, fodder and medicine.
\end{abstract}

\section{Introduction}

Ramsar Convention has defined wetlands as "areas of marsh, fen, peat land or water, whether natural or artificial, permanent or temporary with water that is static or flowing, fresh, brackish or salt, including areas of Marinewaterthedepthofwhichatlowtidedoesnotexceedsixmeters"(http://www.wetlandsofindia.org/wetlands/introducti on.jsp).

Some wetland masses such as ponds or lakes get filled up by the sediments brought down by a river or some other running water course and turn into plains in course of time. Such wetlands may be called lacustrine bed or plains. The water may additionally disappear by natural drainage, evaporation or other geophysical processes from these drying water resources. If the river or running water channel does not carry in sediments, the wetland mass may exist with its overall ecosystem for a long time and would be referred as riverine.

Palustrine wetlands include all non-tidal wetlands dominated by trees, shrubs, persistent emergent plants, or emergent mosses or lichens, as well as small, shallow open water ponds or potholes. Palustrine wetlands are often called swamps, marshes, potholes, bogs, or fens. Such systems include any inland wetland which lacks flowing water (Cowardin et al. 1979; Mitsch and Gosselink 1993; Schot 1999; Charman 2002).

Five wetland masses including at least two usable ponds were selected for study of their physico-chemical parameters, ecosystem networks and biomass distribution in the district of Madhubani (Bihar), India spaced from each other by few kilometers only. All of them fall between 26.471697-26.482645 $\mathrm{N}$ and 86.595633-86.598519 E (Plate I).

These water bodies may conveniently be categorized into (a) reverine, (b) lacustrine, and (c) palustrine systems presently. WB1, WB2 and WB3 are palustrine in nature, while WB4 is riverine in the sense that a tributary canal course flows in river water into the body especially during rains and WB5 may be said to be lacustrine due to the fact that it heavily receives solid sediments from an outside water course, and as such it has degenerated vastly.

\section{Materials And Methods}

Analytical studies in the selected ponds/water bodies were carried out over two years (2010-11), thrice a year (January, May and September). Mean values are presented here. Physico-chemical parameters, biomass and trophic relationships were studied and analyzed as given by Saxena (1987). Ecological simulation software EwE6 (Ecopath with Ecosim 6) (Pauly et al. 2000) was used to derive food chain interactions and biomass interrelations. Additionally, fish population of WB1 was dynamically analyzed with help from FiSAT II (Gayanilo et al. 1996). 
Analytical study of some wetlands for their strategic conservation and positive utilization

Plants were identified with the help of the regional Flora by Haines (1925) while identification of fish was assisted by the publication of Chakraff (1987). Identification of the bird fauna was confirmed by the book by Ali and Futehally (1989).

Before rains, the water catchment area (or bog area) in square foot of the five water bodies WB1, WB2, WB3. WB4 and WB5 was respectively 24025.0, 70125.0, 24872.0, 46276.75 and 2467.5 with maximum water depth in the centre before and after rains (May and September) being 7.0' and 9.5', 3.5' and 4.25', 5.5' and 6.85', 5.75' and $5.75^{\prime}$, and $2.5^{\prime}$ and $7.5^{\prime}$ respectively.

To study and model the WB1 ecosystem, biomass of phytoplanktons (algae), macrophytes, snails and other small animals (zooplanktons), detritus (organic material found suspended in water), and fish fauna was estimated by sampling 10'X10' area one at each side of the water bodies and 10/X10'area in the centre of the pond thrice a year. Mean values of biomass were originally calculated as $\mathrm{kg} / \mathrm{m}^{2} / \mathrm{year}$ on the basis of the average of two years but converted into tonne $/ \mathrm{km}^{2} /$ year for data entry into the EwE6 software.

Biomass of algal flora was also estimated in terms of chlorophyll a content as given by Wetzel and Likens (1991). The concentration of chlorophyll-a was determined by applying the following formula (Talling and Driver 1961) -

$\mathrm{Chl}-\mathrm{a}=\left(27.7 \times\left[\left(\mathrm{E}_{663}-\mathrm{E}_{750}\right)-\left(\mathrm{E}_{663 \mathrm{a}}-\mathrm{E}_{750 \mathrm{a}}\right)\right] \times 10000 \times \mathrm{V} \times \mathrm{d}\right.$

Where, $\mathrm{E}_{\mathrm{xxx}}=$ Absorbance of the given wavelength; $\mathrm{E}_{\mathrm{xxxa}}=$ Absorbance of the given wavelength after acidification; $\mathrm{V}=$ filtered volume of the sample in $\mathrm{ml}$ and $\mathrm{d}=$ path length of the cuvette.

The mean fresh weight biomass of macrophytes was calculated from the biovolume measurements (Asiyo 2003).

\section{Observations And Discussion}

Plate I presents the aerial view (Google map view) of the wetland bodies investigated during the present project with their geographic location shown alongside. Table I presents the mean values of the physico-chemical parameters of the water bodies over two years read in January, May and September.

Mean values of the algal biomass as the average of two years in terms of chlorophyll a ( $\mu \mathrm{g}$ chl-a $1^{-1}$ ) was recorded as 21.54 (Jan.), 12.56 (May) and 48.09 (Sept.) for WB1; 169.8 (Jan.), 186.45 (May), 215.76 (Sept.) for WB2; 11.0 (Jan.), 8.8 (May), 18.4 (Sept.) for WB3; 88.06 (Jan.), 85.35 (May), 17.0 (Sept.) for WB4; and 4.5 (Jan.), 2.5 (May), 11.75 (Sept.) for WB5. The variations in algal biomass of the water bodies are graphically represented by Plate II (a). Plate II (b) presents graphic representation of the mean biomass of different groups of producer organisms. Plate II (c) presents that of the consumer groups. Table II presents the panorama of the existing producer plants and detritus in the five water bodies along with their mean biomass as $t / \mathrm{km}^{2} / y e a r$ while table III presents the same for consumer species of the five water bodies.

The eco-simulation software EwE6 (Ecopath with Ecosim 6) was used to study and model the trophic relationships in WB1 water body only as out of the all five, this pond appeared as most sustainable for aquaculture especially for fish. Table IV presents the sum values of the important parameters of WB1 ecosystem calculated by EwE6 and used for model building by the program. Table $\mathrm{V}$ presents the summary data sheet generated by the EwE6 modeling of WB1 ecosystem.

Plate III presents the flow chart of the WB1 pond ecosystem components as drawn by the EwE6 software. Plate IV presents the Lindeman spine which shows food chain with import and export of food along discrete trophic levels.

Analysis of the physico-chemical characteristics of water and biomass of the standing crop and detritus clearly establish that one of the five ponds (WB5) has already been lost in terms of its basic ecological features and applicability. WB2 is also fast degenerating with high degree of weed invasion and ecological imbalance. WB4 is sustained by incoming water flow that does not carry in sediments. WB3 and WB1 are supported by almost correct ecological parameters that can well sustain a balanced biomass based aquatic ecosystem.

The description of WB1 is based on the estimation of the biomass of the producer and consumer components, detritus and composition of the fish diet. Fish (especially, large ones) constitutes practically the top predator. Birds prey upon small fish only (but placed at highest trophic level by EwE6). Network analysis of a mass-balanced flow web diagram is now a necessary tool used in the modern ecological studies and ecosystem analyses (Moreno and Castro 1998). In the ecosystem modeled, small planktonic algae, floating pteridophytic and angiospermic plants and larger submerged or emergent hydrophytes are placed at a trophic level of 1 along with the detritus. Planktonic insects and snails are placed at a trophic level of 2, while small fish at 2.9, large fish at 3.364 and birds at trophic level of 3.9 . 


\section{Plate I}

\section{Water bodies where studies were carried out}

Lacustrine water body (WB5) has been gradually lost due to sediments brought down by an external water course and turned into peat plain by now. The water disappeared by drainage and evaporation too. Palustrine water bodies (WB1, WB2, WB3) are more or less well-bound ponds and lack inflowing water.

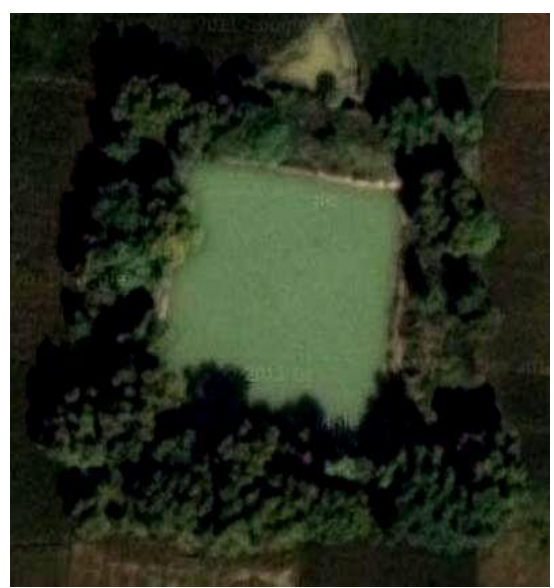

WB1: Palustrine (earlier) $26.47478 \mathrm{~N} 86.596277 \mathrm{E}$

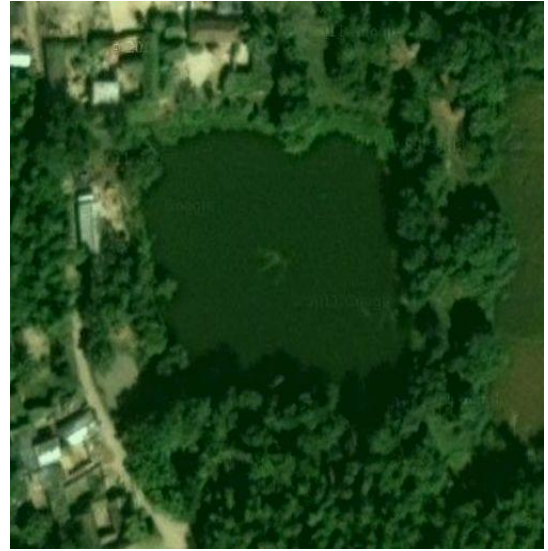

WB3: Palustrine 26.477094 N 86.597993 E

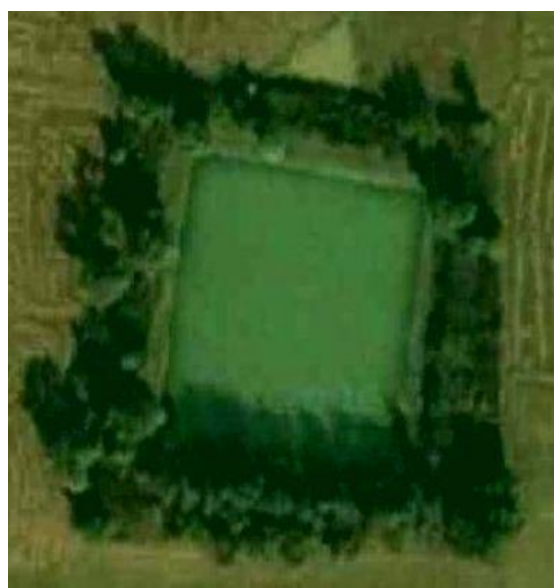

WB2: Palustrine 26.471697 N 86.598519 E

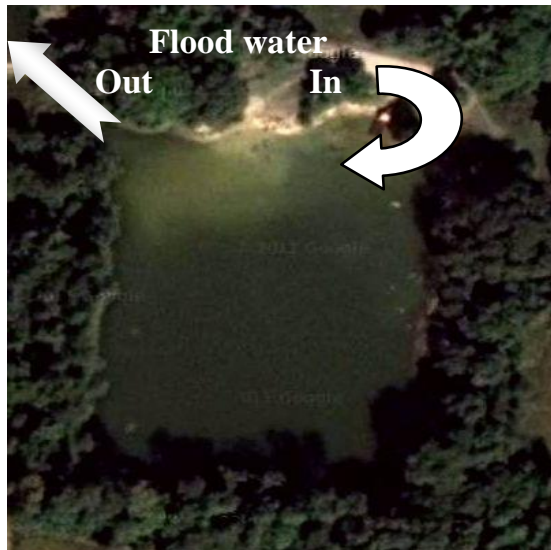

WB4: Riverine 26.482645 N 86.595633 E

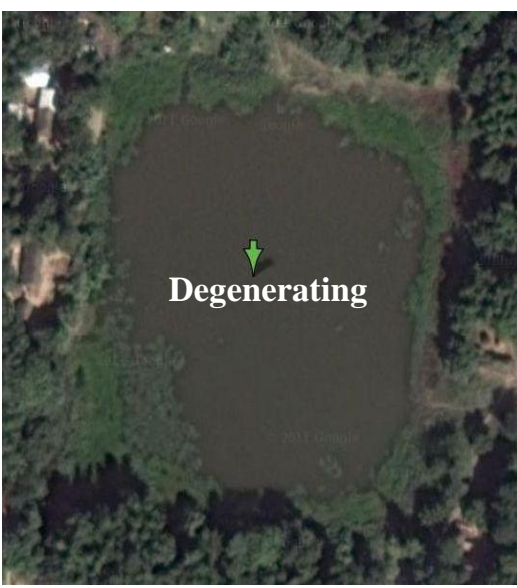

WB1: Palustrine (now)

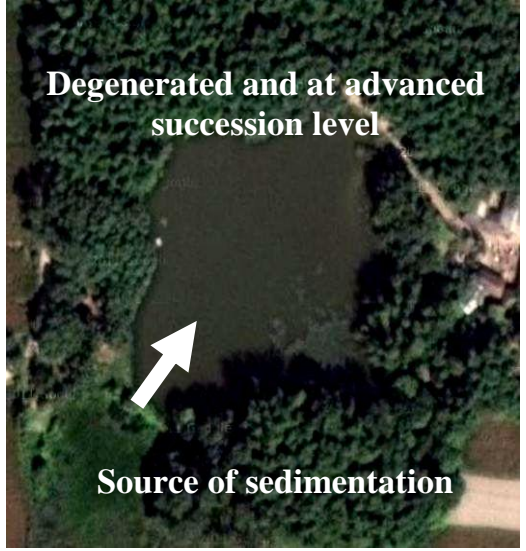

WB5: Lacustrine 26.47816 N 86.595848 E 


\section{Plate II}

Algal biomass as the average of two years in terms of chlorophyll a ( $\mu \mathrm{g}$ chl-a 1-1)

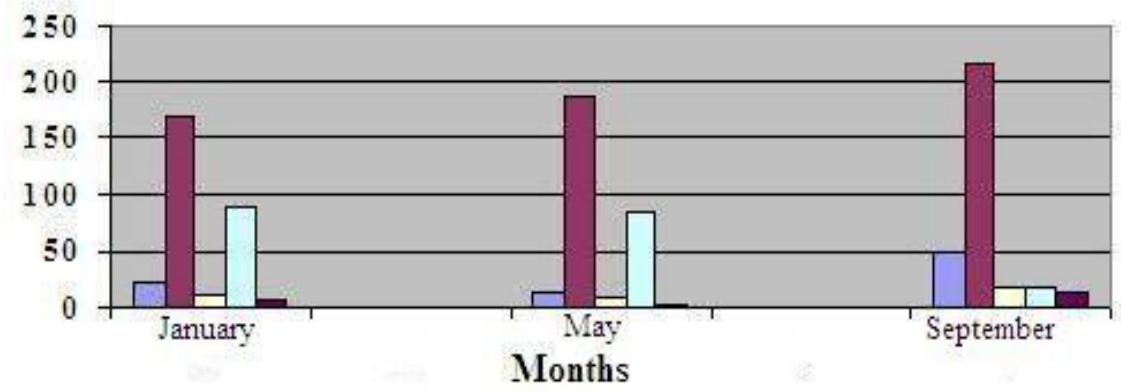

$\square \mathrm{WB} 1 \square \mathrm{WB} 2 \square \mathrm{WB3} \square \mathrm{WB} 4 \square \mathrm{WB} 5$

(a)

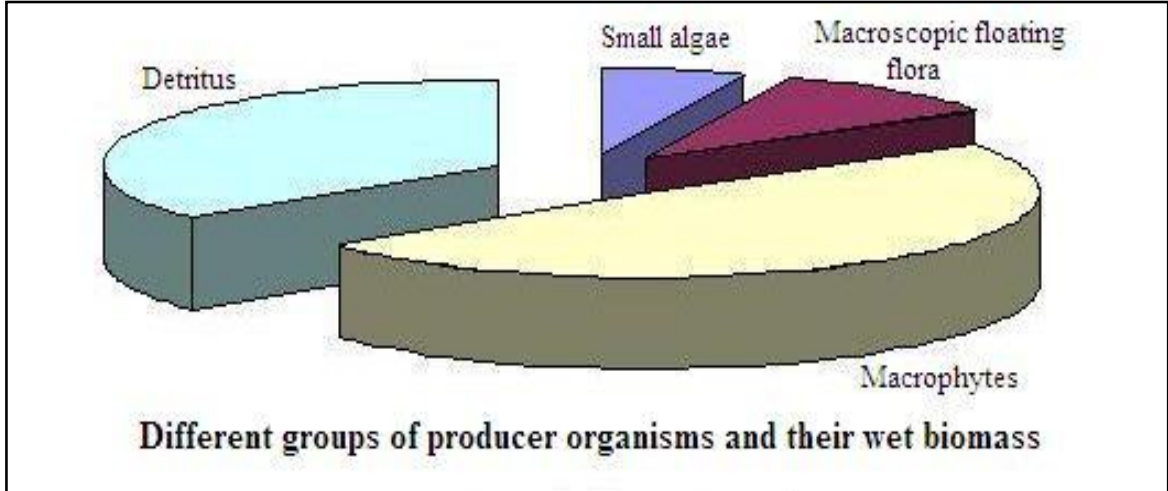

(b)

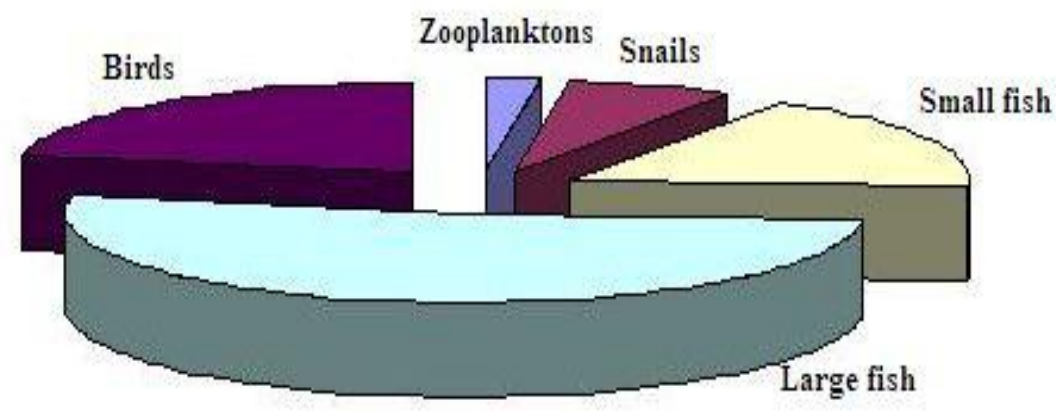

Different groups of consumer organisms and their biomass

(c) 


\section{Plate III}

Flow chart in WB1 ecosystem
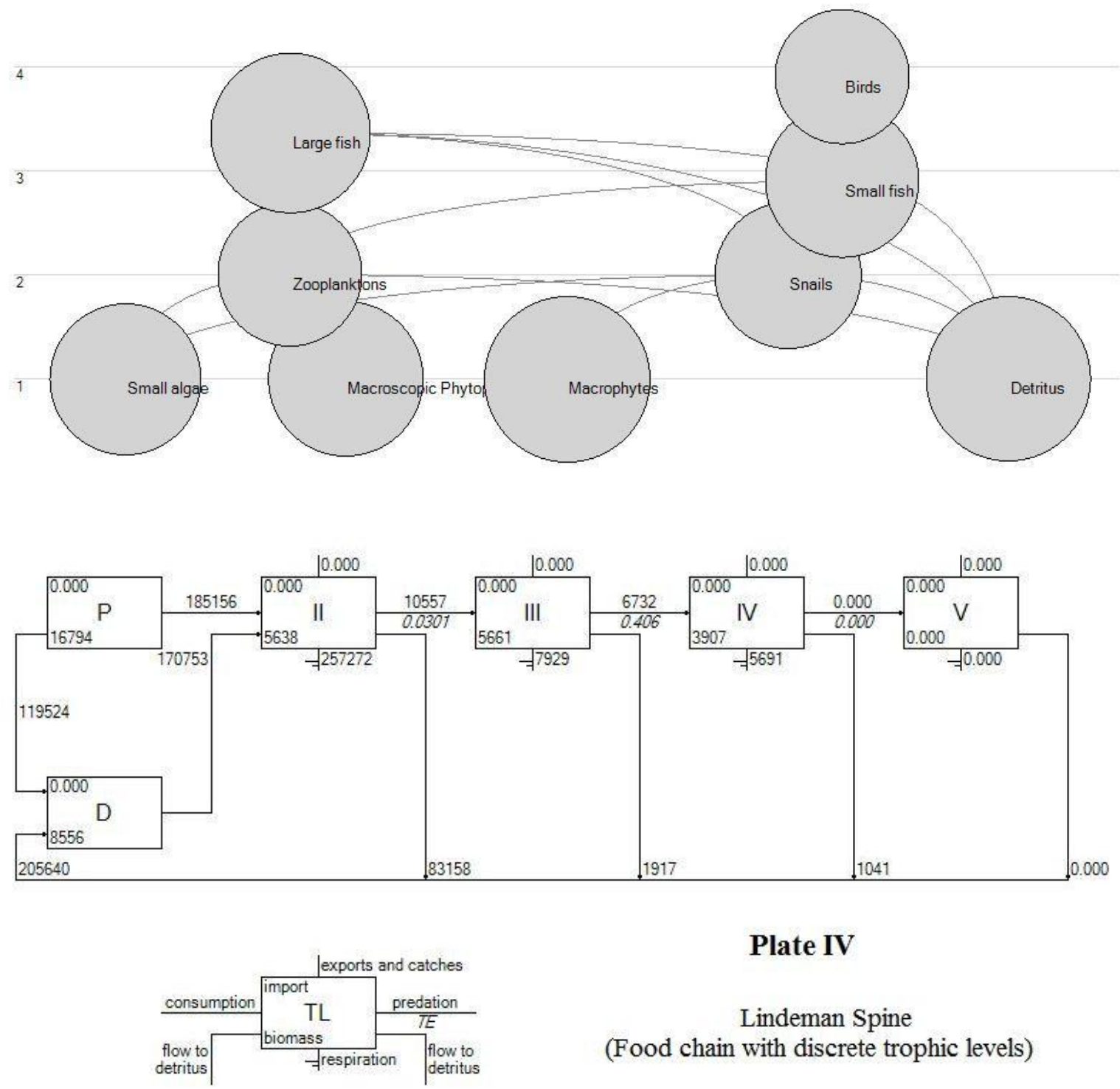

Plate IV

Lindeman Spine

(Food chain with discrete trophic levels) 
Table I.

Mean values of three readings (January, May and September) of water quality parameters over two years (2010-11) in five wetland bodies.

\begin{tabular}{|c|c|c|c|c|c|}
\hline Parameters & WB1 & WB2 & WB3 & WB4 & WB5 \\
\hline $\begin{array}{c}\text { Temperature } \\
\left({ }^{\circ} \mathrm{C}\right)\end{array}$ & 25.5 & 27.56 & 26.0 & 27.45 & 28.9 \\
\hline pH & 7.25 & 6.56 & 7.65 & 7.35 & 6.16 \\
\hline $\begin{array}{l}\text { Conductivity } \\
\text { (ms) }\end{array}$ & 0.175 & 0.225 & 0.184 & 0.272 & 0.412 \\
\hline $\begin{array}{c}\text { Dissolved oxygen } \\
(\mathrm{mg} / \mathrm{L})\end{array}$ & 8.5 & 4.55 & 7.06 & 6.85 & 3.10 \\
\hline $\begin{array}{l}\text { Calcium } \\
(\mathrm{mg} / \mathrm{L})\end{array}$ & 285.67 & 318.75 & 198.77 & 210.15 & 108.06 \\
\hline $\begin{array}{c}\text { Magnesium } \\
(\mathrm{mg} / \mathrm{L})\end{array}$ & 310.0 & 325.66 & 348.90 & 395.54 & 123.22 \\
\hline $\begin{array}{c}\text { Phosphate } \\
\text { (mg/L) }\end{array}$ & 0.45 & 0.86 & 0.35 & 0.58 & 0.95 \\
\hline $\begin{array}{l}\text { Nitrate } \\
(\mathrm{mg} / \mathrm{L})\end{array}$ & 2.35 & 4.16 & 3.25 & 5.67 & 6.75 \\
\hline $\begin{array}{c}\text { Chlorine } \\
\text { (mg/L) }\end{array}$ & 2015.54 & 8423.65 & 5170.0 & 8223.85 & 9115.05 \\
\hline $\begin{array}{l}\text { Total dissolved solids } \\
\text { (mg/L) }\end{array}$ & 5.79 & 8.98 & 6.0 & 6.64 & 12.51 \\
\hline $\begin{array}{c}\text { Total Hardness } \\
\text { (mg/L) }\end{array}$ & 1025.05 & 2650.25 & 1219.15 & 1145.50 & 775.18 \\
\hline
\end{tabular}




\begin{tabular}{|c|c|c|c|c|c|c|c|c|c|}
\hline \multicolumn{4}{|c|}{$\begin{array}{c}\text { Table II } \\
\begin{array}{c}\text { Different groups of producer organisms, } \\
\text { detritus and their biomass }\end{array}\end{array}$} & \multirow{2}{*}{$\begin{array}{l}\text { WB } \\
1 \\
\\
+\end{array}$} & \multirow{2}{*}{$\begin{array}{l}\text { WB } \\
2 \\
-\end{array}$} & \multirow{2}{*}{$\begin{array}{l}\text { WB } \\
3 \\
\\
+\end{array}$} & \multirow{2}{*}{$\begin{array}{l}\text { WB } \\
4 \\
-\end{array}$} & \multirow{2}{*}{$\begin{array}{l}\text { WB } \\
5 \\
\\
-\end{array}$} & \multirow{2}{*}{$\begin{array}{c}\begin{array}{c}\text { Mean } \\
\text { Biomass } \\
\left(\mathbf{t} / \mathrm{km}^{2} / \mathrm{yea}\right. \\
\mathbf{r}\end{array} \\
\\
\text { WB1. }\end{array}$} \\
\hline \multirow{24}{*}{$\begin{array}{l}\text { Producer } \\
\text { Organis } \\
\text { m }\end{array}$} & \multirow{9}{*}{$\begin{array}{l}\text { Phyto- } \\
\text { plankton } \\
\text { S }\end{array}$} & \multirow{5}{*}{$\begin{array}{l}\text { Small } \\
\text { algae }\end{array}$} & $\begin{array}{l}\text { Chlamy- } \\
\text { domonas }\end{array}$ & & & & & & \\
\hline & & & Spirogyra & - & + & + & + & - & \multirow{4}{*}{$\begin{array}{l}\text { WB1: } \\
\text { 3250.5 } \\
\text { WB2: } \\
\text { 2380.67 } \\
\text { WB3: } \\
\text { 2298.98 } \\
\text { WB4: } \\
\text { 2302.0 } \\
\text { WB5: } 0.00\end{array}$} \\
\hline & & & Volvox & + & + & + & + & - & \\
\hline & & & Nostoc & + & + & + & + & - & \\
\hline & & & Microcystis & + & - & - & - & - & \\
\hline & & Macro & Wolfia & - & + & + & + & + & WB1: \\
\hline & & $\bar{s}$ & Azolla & - & + & + & + & + & $\begin{array}{l}4425.68 \\
\text { WR?. }\end{array}$ \\
\hline & & flora & Salvinia & + & + & + & + & + & 5445.56 \\
\hline & & & Lemna & + & - & + & - & + & $\begin{array}{l}\text { WB3: } \\
4333.76 \\
\text { WB4: } \\
3338.89 \\
\text { WB5: } \\
4223.32\end{array}$ \\
\hline & \multirow{15}{*}{$\begin{array}{l}\text { Macro- } \\
\text { phytes }\end{array}$} & & Chara & + & - & - & + & - & \multirow{15}{*}{$\begin{array}{l}\text { WB1: } \\
9117.89 \\
\text { WB2: } \\
\text { 6100.67 } \\
\text { WB3: } \\
\text { 5980.66 } \\
\text { WB4: } \\
\text { 4998.75 } \\
\text { WB5: } \\
7232.06\end{array}$} \\
\hline & & & Nitella & + & - & - & + & - & \\
\hline & & \multirow{13}{*}{$\begin{array}{l}\text { Angio- } \\
\text { sperms }\end{array}$} & Limnophila & + & + & + & - & + & \\
\hline & & & $\begin{array}{l}\text { Ceratophyllu } \\
m\end{array}$ & - & + & + & - & - & \\
\hline & & & Hydrilla & + & + & + & + & - & \\
\hline & & & Vallisneria & + & - & - & + & + & \\
\hline & & & Potamogeton & + & - & + & - & + & \\
\hline & & & Pistia & - & + & + & + & + & \\
\hline & & & Eicchornia & - & + & + & + & + & \\
\hline & & & Hydrocharis & + & + & + & + & - & \\
\hline & & & Nymphaea & - & + & + & + & - & \\
\hline & & & Nelumbium & - & + & - & + & - & \\
\hline & & & Euryale & - & + & - & + & + & \\
\hline & & & Myriophyllum & + & + & + & + & - & \\
\hline & & & Trapa & - & + & + & - & + & \\
\hline
\end{tabular}


Analytical study of some wetlands for their strategic conservation and positive utilization

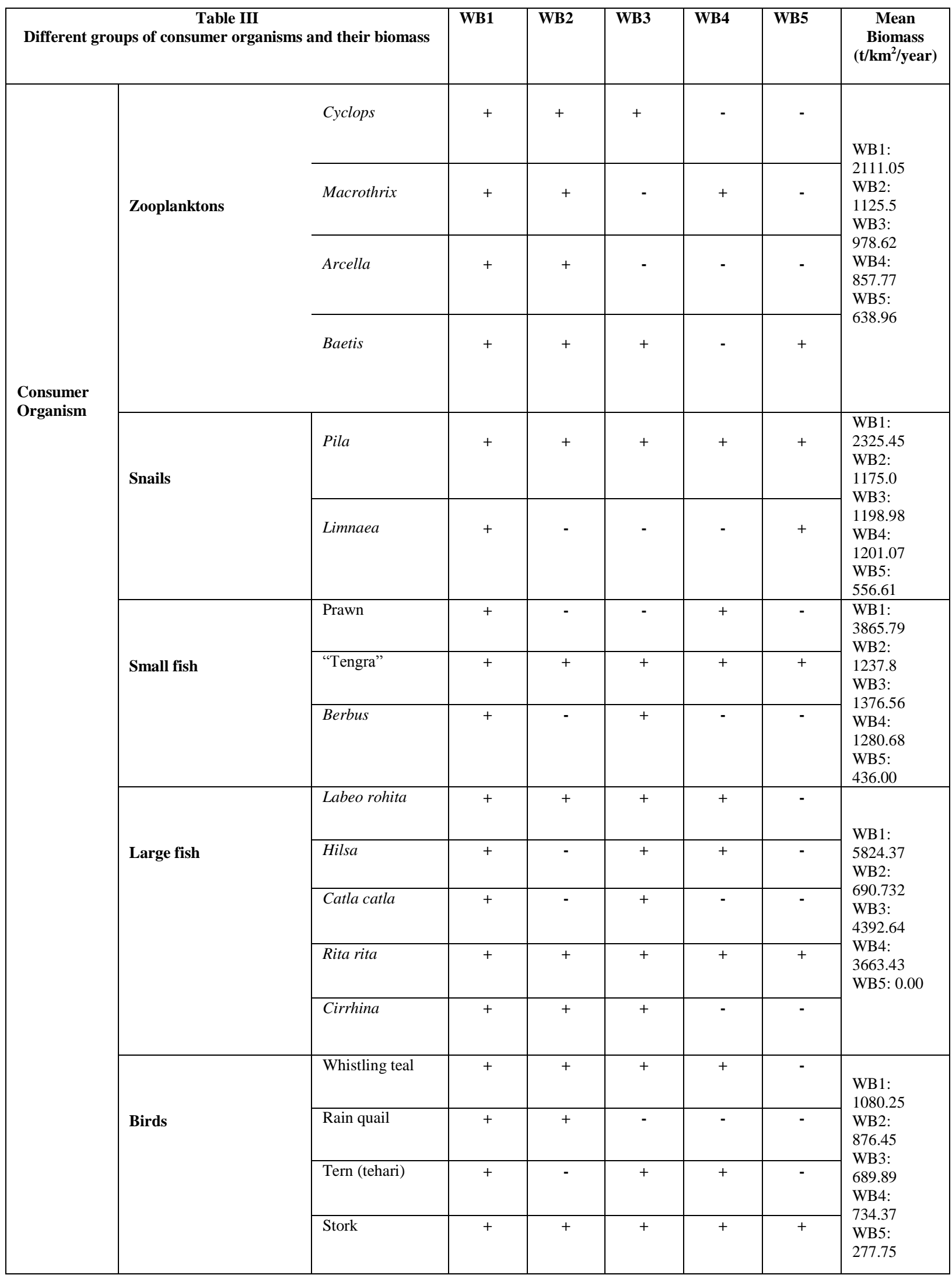




\section{Table IV}

Sum values of the important parameters of WB1 ecosystem calculated by EwE6 and used for model building

Parameter

Sum of all consumption

Sum of all exports

Sum of all respiratory flows

Sum of all flows into detritus

Total system throughput

Sum of all production

Calculated total net primary

production

Total primary production/total

respiration

Net system production

Total primary production/total biomass

Total biomass/total throughput

Total biomass (excluding detritus)
Value

373198.9

54138.66

270891.6

224892

923121.2

355808.6

332885.1

1.22885

61993.5

10.40242

0.0346658

32000.73 


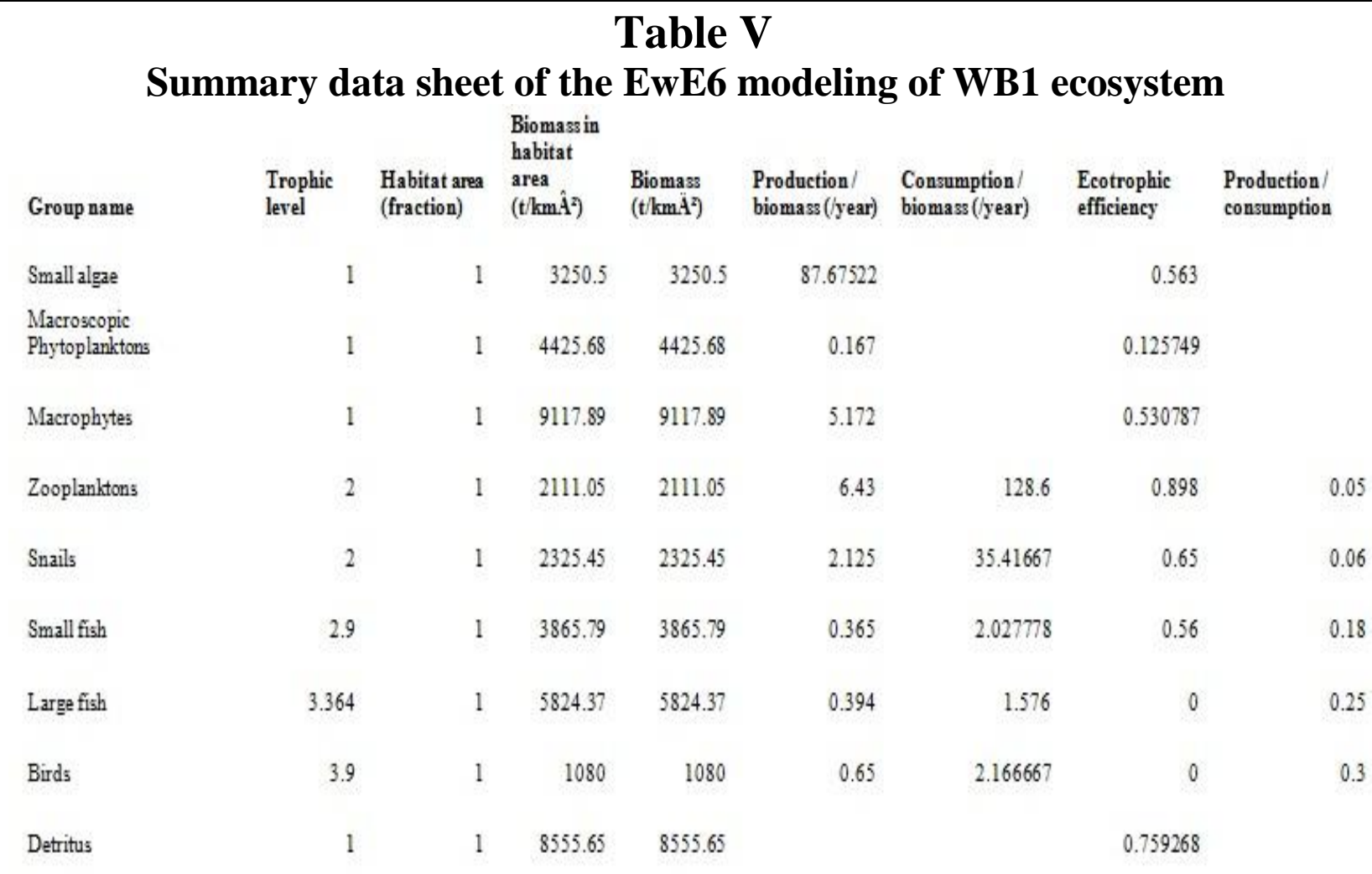

Software application EwE6 required a few parameters in addition to the biomass estimates [e.g. Production $(\mathrm{P})$, Consumption $(\mathrm{Q}), \mathrm{P} / \mathrm{B}, \mathrm{Q} / \mathrm{B}, \mathrm{P} / \mathrm{Q}$ and $\mathrm{EE}$ (Ecotrophic efficiency)]. These parameters were calculated as suggested by Christensen et al. (2008).

In case of wetlands that have not completely degenerated or degenerated vastly into a plain, cybernetic management principles may be applied to control and sustain desirable seral stages of plants and fauna with constrained biotic interference for recovery and commercial usefulness (Kumar 1988). A marsh with fibre yielding grasses is at advanced seral stage than the shallow water condition with rooted plants having floating leaves. Should the latter not advance into the former, measures that should be adopted would include desilting of the body regularly to maintain water level, regular eradication of free floating weeds which enhance aging of the habitat, and development plan for water flow designs for sanitation and irrigation both (Kumar and Hafiz 2000). A number of useful plants can separately be selected for commercial utilization and exploitation of degenerated wetlands (Kumar and Hafiz 2000).

A common marsh loving plant Typha angustifolia Linn. is a good option for cultivation in degenerated wetlands to recover the productivity of the wasting land mass in terms of fibre, food, medicine and as a buffer stand to absorb and get rid of heavy metals and hard pollutants (Kumar and Sheel 2007). Fibre yield from this plant is of multiple use (Singh and Kachroo 1976), its starch-rich roots, rhizome, flowering shoot and pollens are highly nutritious and source of proteins (Facciola 1990), its different parts are medicinally useful (Duke and Ayensu 1985; Him-Che 1985; Gao and Liao 1998). Additionally, the plant shows high degree of tolerance towards heavy metals, and, accumulation of metals like $\mathrm{Cd}, \mathrm{Cr}, \mathrm{Cu}, \mathrm{Fe}, \mathrm{Mn}, \mathrm{Ni}, \mathrm{Pb}$ and $\mathrm{Zn}$ (Panich-pat et al. 2005). Mercury disposal ability introduced into this plant by transfer of the mercury metabolizing genes of the mer operon of a mercury resistant bacterial strain has made it the most desirable taxon to be cultivated in ecologically degenerated wetlands (Kumar and Sheel 2007). 
[1] Ali S and Futehally L 1989 Common birds. $6^{\text {th }}$ edition. National Book Trust, New Delhi, India.

[2] Asiyo SG 2003 The Phytoplankton Primary Productivity, biomass and Species Composition in the Finger ponds (Uganda). A thesis submitted to the Department of Environmental Resources of the International Institute for Infrastructural Hydraulic and Environmental Engineering for partial fulfillment of the requirements for the degrees of Master of Science in Environmental Science and Technology.

[3] Chakraff M 1987 Fresh water fish pond culture and management. Scientific publishers, Jodhpur, India.

[4] Charman D 2002 Peatlands and environmental change. J. Wiley \& Sons, London \& New York.

[5] Christensen V, Walters CJ, Pauly D and Forrest R 2008 Ecopath with Ecosim version 6 User Guide. Lenfest Ocean Futures Project. www.ecopath.org/

[6] Cowardin LM, Carter V, Golet FC and La Roe ET 1979 Classification of wetlands and deepwater habitats in the United States. U.S Dept. Interior, Fish \& Wildlife Service, FWS/OBS-79/31.

[7] Duke. J. A. and Ayensu. E. S. 1985 Medicinal Plants of China Reference Publications, Inc. ISBN 0-917256-20-4.

[8] Facciola. S. 1990 Cornucopia - A Source Book of Edible Plants. Kampong Publications. ISBN 0-9628087-0-9.

[9] Gao G and Liao M 1998 Determination of flavonoids and quality evaluation of Chinese traditional drug "Puhuang". Yaoxue Xuebao 33(4): 300-303. Inst. Med. Plant, Chinese Acad. Med. Sci. and Peking Union Med. Coll., Beijing 100094, China.

[10] Gayanilo FC Jr., Sparre P and Pauly D 1996 FAO-ICLARM stock assessment tools (FiSAT). User's guide. FAO Computerized Information Series (Fisheries). No. 8, Rome, FAO.

[11] Haines HH 1925 (Reprint 1999) The Botany of Bihar and Orissa. Bishen Singh Mahendra Pal Singh, Dehradun, India.

[12] Him-Che, Y. 1985 Handbook of Chinese Herbs and Formulas. Institute of Chinese Medicine, Los Angeles.

[13] Kumar J 1988 Cybernetic management of ecosystems for environmental management. Proceedings of National Workshop on Technology delivery system for rural development, NIWARD, New Delhi, India.

[14] Kumar J and Hafiz A 2000 Schematic conservation of wetlands of Bihar. Int. J. Mendel 17 (1-2): 17-18.

[15] Kumar J and Sheel R 2007 Suitability and utility value of Typha angustifolia Linn. for cultivation in North Bihar countryside wetlands. Paper presented at the National Conference on Under-utilized and under-exploited plants of wetlands. 27-28 Oct 2007. B.N. College, Patna (Bihar), India.

[16] Mitsch WJ and Gosselink JG 1993 Wetlands (2 $2^{\text {nd }}$ ed.). Van Nostrand Reinhold Co., New York.

[17] Moreno T and Castro JJ 1998 Trophic structure of the Maspalomas lagoon (Gran Canaria, Canary Islands), a regenerated ecosystem of brackish water. Bol. Mus. Mun. Funchal, Sup. No. 5: 245-261.

[18] Panich-pata, T., Srinivesb, P., Kruatrachuec, M., Pokethitiyookc, P., Upathamd, S. and Lanzae, G.R. 2005 Electron Microscopic Studies on Localization of Lead in Organs of Typha angustifolia Grown on Contaminated Soil. ScienceAsia 31: 49-53

[19] Pauly D, Christensen V and Walters C 2000 Ecopath, Ecosim, and Ecospace as tools for evaluating ecosystem impact of fisheries ICES Journal of Marine Science. 57: 697.

[20] Saxena MM 1987 Environmental analysis. Agro-Botanical Publishers, Bikaner, India.

[21] Schot PP 1999 Wetlands. In: Nath, B. et al. (eds.), Environmental Management in Practice 3: 62-85. Routledge, London \& New York.

[22] Singh, G. and Kachroo, P. 1976 Forest Flora of Srinagar. Bishen Singh Mahendra Pal Singh, Dehradun, India.

[23] Talling JF and Driver D 1961 Some problems in the estimation of chlorophyll-a in phytoplankton. In: Proceedings of the conference on primary productivity measurement, marine and freshwater, held at University of Hawaii, August 21-Sept. 6 1961

[24] Wetzel RG and Linkens GE 1991 Limnological analyses. $2^{\text {nd }}$ Edition. Springer-Verlag. New York. 